\title{
Reactive Depression
}

National Cancer Institute

\section{Source}

National Cancer Institute. Reactive Depression. NCI Thesaurus. Code C34533.

Depression precipitated by events in a person's life. 